and became lecturer in othopaedic surgery at University College. Ibadan. He was largely responsible for the organisation of the orthopaedic services in Nigeria, and the development of orthopaedic surgery in that country is in great measure due to his energy, tact and skill. Those who visited him in Nigeria were greatly impressed by his work in difficult circumstances. Nine years ago he was invalided out of the Service and returned to Britain, where he was appointed consultant orthopaedic surgeon to the Beckett Hospital, Barnsley, and to the King Edward VII Orthopaedic Hospital, Sheffield. At Barnsley he devoted his great energy and ability to the development of a comprehensive accident and orthopaedic service. The excellence of this department will be a lasting memorial. He was a member of the British Orthopaedic Association and a much loved member of the Yorkshire Orthopaedic Club.

Tom Lawson was a delightful man, full of Irish charm and wit and with great ability. $\mathrm{He}$ had wide interests, and was particularly fond of sailing and of all country pursuits. His colleagues in South Yorkshire had the greatest

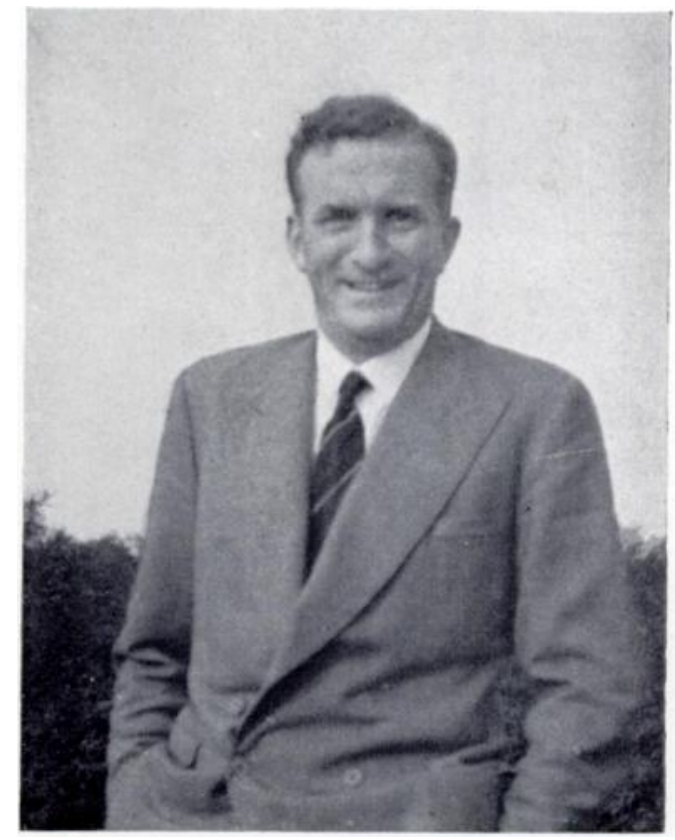
affection and respect for him. His patients adored him. We all grieve at the loss of a devoted surgeon and loyal friend, and extend our sympathy to his widow and his two daughters.

F. W. H.

\title{
LENNOX GRAHAM TEECE
}

1889-1959

All members of the Australian Orthopaedic Association were shocked to read in the press of the sudden death in his sleep of Mr Lennox Graham Teece while touring in France with his wife.

He had not been very fit for some years and consequently had given up skiing and golfing, but he continued to enjoy the races. I met him over twenty-five years ago while on a skiing holiday at Mount Kosciusko with the Australian Ski Club. Lennox, one of the senior members. was at that time a great leader of touring parties on the Main Range of the Australian Alps. His tall athletic figure was invariably in the lead, and the pace set was one which even beginners could follow. He learned his skiing in the days before the Aarlberg technique became popular. and no one at that time could execute a nicer telemark turn. Apart from his tirelessness he was so considerate of young inexpert tourists that each trip was a great success and enjoyed by all. During his winter holidays in Australia, and on occasion in New Zealand, he came in for much work in treating the injuries of this sport. This he did with efficiency and charm. He was a keen member of the club in evenings at bridge or poker, which he played very well. As an after-dinner speaker he was without a peer, not only in the ski club, but in the Australian Orthopaedic Association. With all his qualities it is natural that we remember his period of presidency as one of the most successful.

Vol. 41 B, No. 3, AUguSt 1959 
Lennox became interested in orthopaedics during the first world war, when he became associated in the Military Orthopaedic Hospital at Shepherd's Bush with Sir Robert Jones, McCrae Aitken and Naughton Dunn. On returning to Australia he decided to confine his practice to orthopaedics, and he was appointed Orthopaedic Surgeon to the Royal Prince Alfred Hospital, a position he held until he retired. Lennox was therefore one of the pioneers.

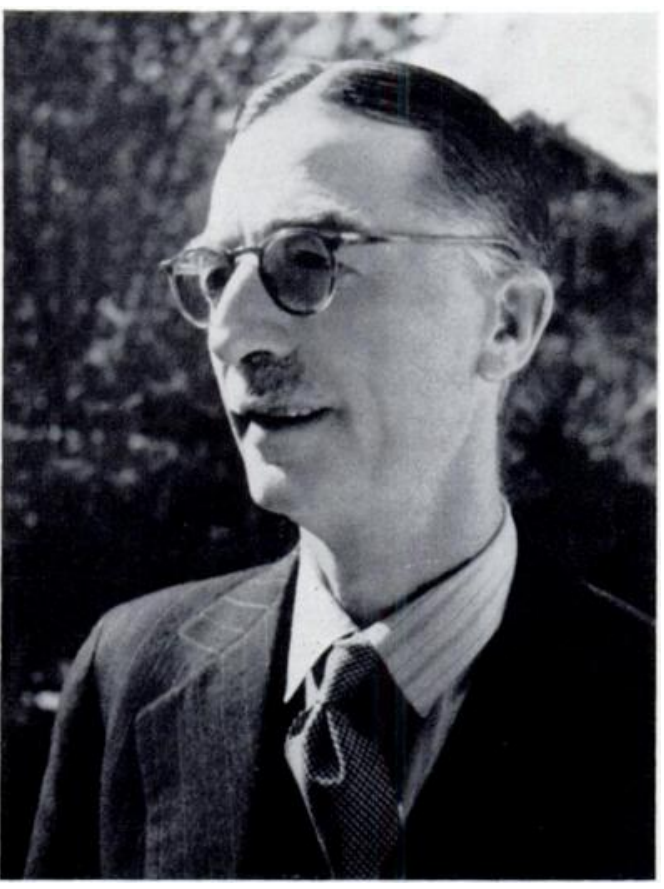
if not the pioneer, of orthopaedic surgery in Australia. He soon developed a large practice in addition to his work at the Royal Prince Alfred Hospital. No one, I believe, in Australia has operated on so many internal derangements of the knee joint. Because of his brilliant mind and ready wit his practice in medico-legal work became enormous.

Throughout his life his home was very happy and, like the Island in Mary Rose. it "liked to be visited." His dogs, Rudolf and Hansel, continue to look out for him about the time he usually arrived home from work. To his widow Allison, his son and daughter warm sympathy is extended.

J. B. C.

J. H. writes: "I am indebted to Mr Eric Fisher, who knew Lennox Teece well at school and during his university career, and who delivered the memorial oration in St Stephen's Church. Macquarie Street, Sydney, soon after the sad news of his death reached us.

“Lennox Teece graduated in 1913, top of his year at the Sydney University, and became Resident Medical Officer at the Royal Prince Alfred Hospital; Senior House Superintendent following Harry Clayton when he went to the war. Soon after Lennox journeyed to England, and joined the Royal Army Medical Corps. On his return to Australia he was appointed Director of the newly established Department of Orthopaedic Surgery at the Royal Prince Alfred Hospital, in which position he remained until he reached the retiring age.

"In October 1936 a meeting of ten surgeons interested in orthopaedic surgery was held to discuss the advisability of forming an Association of Orthopaedic Surgeons. E. B. Vance was voted to the chair, and when the Australian Orthopaedic Association was formed he became the first president. Lennox was, of course, a foundation member, and remained active until his departure on the ill-fated trip abroad in February 1959. He filled various offices in the Association, and became its President in 1953. His contributions to discussions were always to the point, and frequently enlivened by flashes of his well known native wit, which made him a welcome after-dinner speaker.

"Apart from his professional work he was one of the best known ski runners in New South Wales. He became interested in the sport when Resident Medical Officer at the Royal Prince Alfred Hospital, and he took a turn as medical officer at the old Hotel Kosciusko. His colleagues of the snow speak of his unexpected toughness on long trips. Quoting from Eric Fisher: 'He was long. lean and leathery and finished as fit as anybody.' Among his other interests were racing - he attended most of the meetings at Randwick-and bridge and poker, at which he played a good hand. The news of his death came as a bomb to most of us, who were unaware he was not in his normal health. He is greatly missed." 
H.C. B. writes: “ Lennox Teece graduated at Sydney University in 1913, and soon afterwards became Assistant Medical Superintendent of the Royal Prince Alfred Hospital. He was rejected for war service with the Australian Army Medical Corps, but later went to England and joined the Royal Army Medical Corps. As a young medical officer he was directed to the Army Hospital at Shepherd's Bush and there came under the influence of Sir Robert Jones and the team of young orthopaedic surgeons that were working with him. One who appealed to him in particular was Rowley Bristow. He remained at Shepherd's Bush for eighteen months, and soon became absorbed in the problems of war wounded. On his return to Australia in 1918 he had made up his mind to specialise in orthopaedic surgery, and he was put in charge of a new department at the Royal Prince Alfred Hospital. He was followed home soon afterwards by Denis Glissan and Arthur Meehan. These three were the pioneers of orthopaedic surgery in Australia, and all three have now passed on.

"He was a Foundation Fellow of the Australian Orthopaedic Association and of the Royal Australasian College of Surgeons, and he became President of the Association in 1953. He contributed articles on a variety of orthopaedic subjects, including tendon injuries, club foot and lesions of the shoulder and of the knee. His main interest lay in disorders of the knee joint, and he chose this subject for the first Meehan Memorial Lecture in Brisbane in 1956. This was based on two thousand meniscectomies. He devised a test for the detection of posterior horn tears in semilunar cartilages that has been widely adopted in Australia. Apart from a large private practice, he developed almost a monopoly over workers' compensation work in Sydney for many years. He had the gift of clear concise expression, both in his written reports and also when giving evidence in court. It was often felt that he could have graced the bar table as easily as the witness box.

"Away from his work he had many interests including skiing, tennis, golf, surfing and racing. His clear thinking, good humour and quick wit were assets at meetings of the Australian Orthopaedic Association and his after-dinner speeches on such occasions will remain memorable events for many years to come."

vol. 41 B, No. 3, AUGUST 1959 